\title{
Do High Customer Bank Deposits Incite Management Fraud? Examining Causes of Management Fraud in the Nigerian Banking Sector
}

\author{
Paul Ojeaga \\ PhD Bergamo University Italy \\ Email: paul.ojeaga@unibg.it \\ Ikpefan O. PhD \\ Covenant University Ota Nigeria \\ Deborah Odejimi PhD \\ Igbinedion University Okada Nigeria
}

Doi:10.5901/jesr.2014.v4n6p331

\begin{abstract}
The study investigates factors that incite fraud in the banking sector in Nigeria, using times series data for fraud obtained from CBN data from 1998 to 2010. It was found that high bank deposit were primarily responsible for a high rise fraudulent occurrences in the Nigerian banking sector particularly management fraud, some other factors that were also jointly responsible for these occurrences include high interest rates, low commercial bank lending and poor oversight function by the Central Bank and other financial regulatory agencies. The method of estimation used in the study is the quantile regression estimation method which is a non parametric estimation method based on the premise that the sample median will tend to that of the distributional median, it presents some obvious advantages over OLS (ordinary least squares) estimates, since the results are robust in the presence of outliers and heteroscedastic errors in the response measurement and allows for the exploration of other central tendencies and statistical dispersion properties of the dataset Machando and Silva (2013). The results are robust even after controlling for presence of heterscedastic error in the response measurement as well re-sampling the dataset (conducted by the bootstrapped quantile regression technique). Further explanation is also provided for the implication of variables identified to drive fraud occurrences using kernel density estimation.
\end{abstract}

Keywords: Bank deposits, fraud, investors perception, interest rates and quantile regression.

\section{Introduction}

Fraud can be defined as a tricky and dishonest sharp practice carried out by an individual with the intent to gain undue advantage, be it monetary or material. How to curb fraud in the Nigerian Banking sector has generated lots of heated arguments in recent times CBN report 2007 states that the total amount of attempted fraud recorded in the first half of the year 2007 almost exceeded that of the whole of year 2006 see CBN 2007 report and Adeyemo (2012) . Fraud is also a menace that has the capability of destroying financial institutions and harming investor's perception about the banking sector of the affected country. Ways of achieving a zero tolerance to fraud continue to remain a focal point of debate among scholars and policy makers.

Cases of fraud are on the increase in the Nigerian banking sector today, despite the clamp down on fraudulent bank executives by the Central Bank of Nigeria in 2010. Till date no effective measure can be said to have been put in place to prevent fraud in its entirety anywhere in the World. Many Nigerian commercial banks continue to accumulate high financial deposit base without actually effectively lending in a commensurate way to investors and business organizations in the real sector. Many a times the rules for lending are very stringent making the lending process very cumbersome for private businesses genuinely in need of access to capital for further production purposes.

In the last quarter of the last decade bank regulation in Nigeria became so lapse that bank officials were able to accumulate private wealth of unthinkable proportions and commercial banks often found it difficult to distinguish between its assets and those of major shareholders who incidentally became the CEO of such banks leading to a high spate of banking irregularities particularly at the management levels in banks. 
The chief question that this paper tries to answer is the role that high bank deposit plays in fraud prevalence in commercial banks in Nigeria. At this juncture it will be quite necessary to describe what we mean by bank deposits. One of the recent trends that is quite visible in many Nigerian commercial banks is the upsurge in savings that is attributable to increases in wage rates particularly in the early 2000 s, this has led to a high level of customer savings in banks see CBN statistics, 2012.

Also the continuous expansion and sustained growth of the economy also mean that private businesses were also beginning to save up capital and commercial banks are often the first point of interest. The level of savings by individuals and private enterprises have not been well accompanied by strong banking activities such as private sector borrowing particularly at a time when interests are fairly low compared to the 1990s. Banks have therefore been swimming in a gloat of unutilized customer funds creating opportunity for a high level of management fraud occurrences in many Nigerian commercial banks.

This paper studies the dynamics between high customer deposits and management fraud in the Nigeria banking sector, past studies Adeyemo (2012), Ikpefan (2007) and Akindele (2011) have studied the nature, effect and catalyst of fraud in the Nigerian banking system and have concluded that fraud was deeply seated, has a negative effect on investors perception of the banking sector and that lack of transparency and poor commercial banking activities in the banking sector were largely responsible for a high occurrence of fraudulent activities in Nigeria banks.

Few studies if any have emphatically studied the relationship between high bank deposits and management fraud occurrences as we do in this study. The rest of the study is divided into the scope and objective of study, review of literature, stylized facts on fraud and bank deposits, theory and methodology, data and sources, empirical analysis and results and the concluding sections.

\section{Scope and Objective of Study}

The study revisits the fraud paradigm and tries to establish a relationship between high bank deposit and fraud in the still developing Nigerian banking sector. It addresses issues leading to fraudulent occurrences in the banking sector with aim of offering a new incite to the factors responsible for the prevalence of fraud in the banking sector. The objectives of the study include:

a.) To determine the extent to which high customer bank deposits incites management fraud in the Nigerian banking sector?

b.) To determine if bank staffs wage rates were sufficiently deterring fraudulent occurrences in banks in general?

c.) To investigate if commercial bank lending to the private sector was reducing incidences of fraud in the Nigerian banking sector?

\section{Review of Literature}

Lots of studies have studied the catalyst of fraud in many economies. Akindele (2011), states that fraud in bank really leads to loss of money that belongs to someone else other than the bank. Ogwuma (1985) also worries about the prevalence of fraud stating that fraud is not uncommon in the banking sector but that the prevalence of fraud is what can result to a crippling effect of the banking sector of an economy.

Other studies classify and explain in details lapses that can lead to fraudulent occurrences in banks, the study by Adewunmi, (1985), Cahill, Chen and Lambert (2002) and Hulthen et al (2002) argue that institutional and societal lapses are largely responsible for most of the fraudulent occurrences in a country's banking sector which is particularly true since poor oversight function due to poor institutional structures by regulatory agencies and poor wages and societal decadence is likely to incite fraud.

The study by Crosse and Hempel (1973) and Canhil M et al (2002) identifies five major types of fraud perpetrated in the banking industry as borrowing without the intentions to repay, forgeries of customer's signature, transfer from customers account to collaborator account granting of loans to fictitious borrowers and granting of loan without adequate security and information. They however fail to address issues of management fraud in a concrete manner; however the study by Ajisebutu (2006) explains that management fraud is characterized by overstatement of assets or revenues and understatement of expenses or liabilities. The Association of Certified Fraud Examiners (ACFE) also identifies five major characteristics of management fraud as fictitious revenues, timing differences, improper assets valuation, concealed liabilities and expenses and finally improper and/ or inadequate disclosure.

Fakunle (2006) pp. 176 also states that management fraud is the manipulation of records and accounts typically 
by senior management staff of banks with the aim of benefiting indirectly from it. One of the main aims of management fraud according to Adeyemo (2012) is to rake in more investment from existing and potential shareholders and stakeholders into the organization. Idowu (2009) makes a list of different types of fraud common in Nigeria toady to include; advance fee fraud, forged cheques, cheque kitting, accounting opening fraud, counterfeit securities, funds transfer fraud, letter of credit fraud, credit fraud clearing fraud etc.

Foos, Norden and Weber (2007) explains that one of the major responsibilities of banks is to lend to the general public which is a core and major responsibility of commercial banks and that a lot of riskiness is often associated with loan giving and this an integral reason why banks exist see also Diamond (1984) and Bhattacharya and Thakor (1993). They also outline the risky lending environment and factors often responsible for commercial banks ability to lend such as interest rates, stringent credit conditions as well prevailing micro and macro economic conditions such as wage rates, current mortgage value conditions etc.

Logan (2000) also suggest that most bank failures occur as a result of credit boom and bust cycles, recklessness, fraud and poor management. Since bank failures are often rare occurrences Hardy (1998) states that when they do occur they occur in clusters in times of financial contraction making it very difficult to predict using econometric techniques when bank crisis are most likely to happen. Therefore most pre-crisis analysis are often cross-sectional survey that try to conjecture reasons why most financial crisis occur,

This study contributes to the body of knowledge by trying to address the link between high bank customer deposits and fraud in the Nigeria banking sector, while previous studies have tried to address issues related to the after match of fraudulent consequences, this paper tries to deal with pre fraud causes with the aim of identifying factors that are responsible for the occurrences of fraudulent bank practices in the banking sector. The importance of this study is likely to be useful to central planning and regulatory bodies such as the Central Bank of Nigeria (CBN), Nigeria Deposit and Insurance Corporation (NDIC), the Association of Certified Fraud Examiners (ACFE) and a host of other local and international regulatory agencies.

\section{Stylized Facts on Fraud and Bank Deposits}

In this section we present recent trends in the Nigeria economy related to the topic under investigation. Fraud is on the increase and cases of fraud have almost double in the Nigerian banking industry since 2007 this is consistent with CBN report 2007. Bank deposit has also soared and is continually on the increase it is expected to soar as long as the economy does not

Fig. 1. Fraud in Billions of Naira

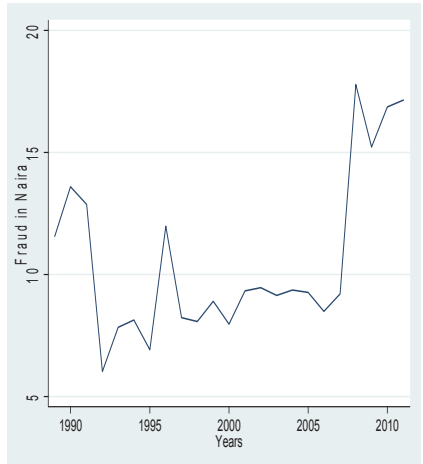

Fig.2. Deposits in Trillions of Naira

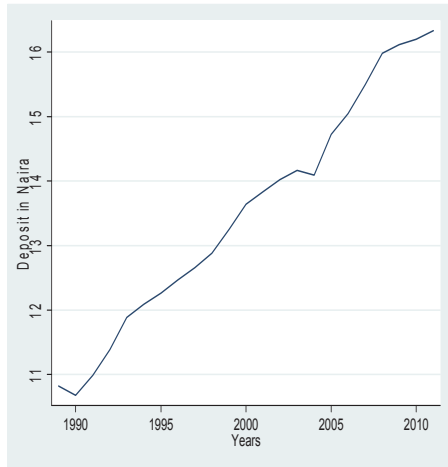

Note: Fig 1 shows the trend in fraud occurrences in years frau is on the increase, significant increases were most noticeable in the late 2007 despite strong bank oversight regimes and prosecutions. Fig 2 shows customers savings deposits in Trillions of dollars, this has increased dramatically with the continuous increased in workers wage rates and growth of the Nigerian economy.

Experience any major contraction that is likely to affect wage rates, reduce employment as well as reduce output production in the private sector of the economy, showing a likely positive relationship between bank deposit and fraud.

The strength and effectiveness of the CBN monetary policy has also fallen drastically, and has managed to return 
to the 1997 peak, only in 2010 with the implementation of central commercial bank reforms in 2010 by the current Nigerian Central Bank administration under Lamido Sanusi. Aggregate money supply has also shrank considerably this is attributable to the mergers and bank consolidations embarked upon in the early and late part of the last decade by the Central Bank of Nigeria.

Fig. 3. Index of CBN Monetary Policy Fig.4. Aggregate Money Supply in Naira
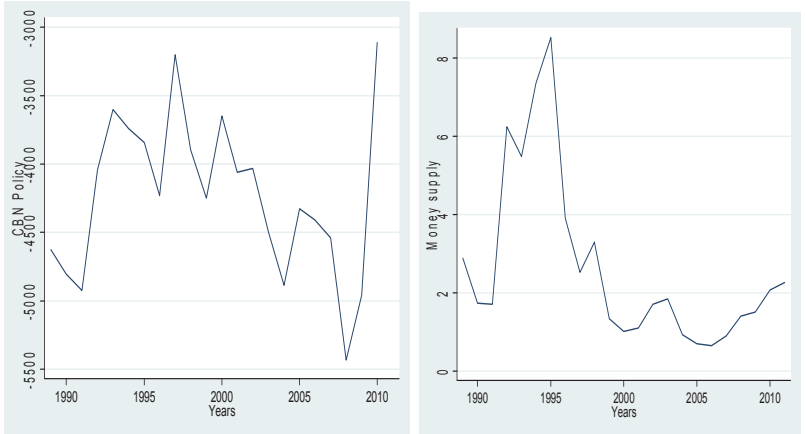

Note: Fig3 depicts the index of CBN Policy which is constructed from CBN from the monetary policy and strength of its oversight functions this trend shows its effectiveness in years which has experienced strong decline until 2008 with the implementation of central bank reforms by the past and present CBN administration in Nigeria, while Fig 4 shows the trend in aggregate money supply this was obtained from CBN data in trillions of Naira considerable shrinkage in money supply in the 2000s was as a result in the Bank consolidation exercises carried out in the Nigeria banking sector.

Trends also show that FDI has also declined and has not managed to return to the pre 1995 periods this was probably attributable protracted military rule and sanctions imposed on Nigeria in the aftermath of diplomatic row with the west particularly the United States of America during military rule. FDI only began to experience some relative increase with the re-established democratic rule in 1999.

The Nigeria economy was also affected by the 2007 world economic crisis attributed to the US sub-prime mortgage crisis. Interest rates have till date remained at an all time high since the financial crisis and has not declined to previous values of the early 2000s it was also affected by the 2007 financial crisis when it experienced a strong increase this was attributable to the riskiness of the financial environment and the likelihood of borrowers to default due to the impending global contraction, and fears of possible contagion since the world economy is now closely linked. . Other issues such as poor legal rights enforcement also affects investor's perception and deters the inflow of foreign capital into the Nigerian economy.

Fig.5. FDI inflow in Billions of Dollars Fig. 6 Average Interest Rates in Percentages
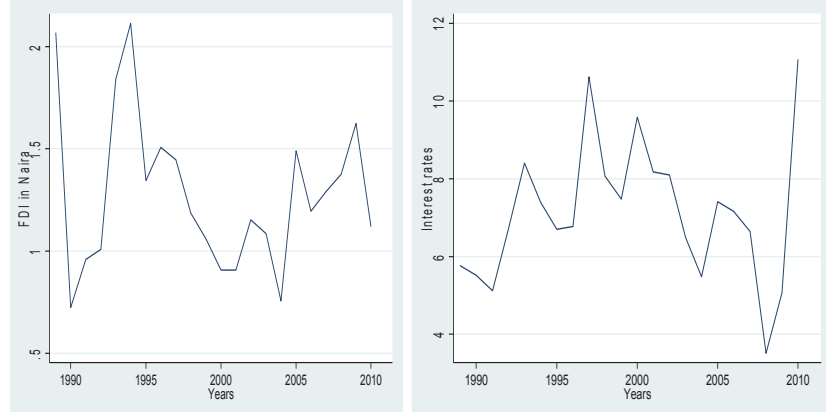

Note: Fig 5 shows FDI inflow in years to the Nigerian economy Nigeria has experienced noticeable increase in foreign investment since 2006 after significant decreases in the mid 1990s. Fig 6 shows average nominal interest rates in percentages which has experienced a sporadic increase since the 2007 global financial crisis. 
Bank losses is also on the increase, the nature of the losses are largely attributable to fraudulent occurrences in banks particularly management fraud which currently accounts for over $75 \%$ of the total losses from fraud in the Nigeria banking sector and default by lenders particularly in the 2007 post crisis periods (CBN report, 2007). Other factors responsible for losses also include poor training and lack of in-depth experience and poor on the job training exercises of the management staff of many commercial banks of the fundamentals of commercial banking in Nigeria.

Legal rights enforcements are also on the decline; this also has strong implication for the financial sector of the Nigeria economy since this is likely to have no effect on fraud reduction. Past studies also posit that the African institutional framework is dysfunctional Ross (2001) and therefore weak having no significant effect on growth, the expectation is that legal rights enforcements is likely to have a negative or no effect also on investors perception and depositors behavior in the Nigerian banking sector.

Fig. 7. Aggregate Commercial Bank Losses Fig.8. Legal Rights Enforcements
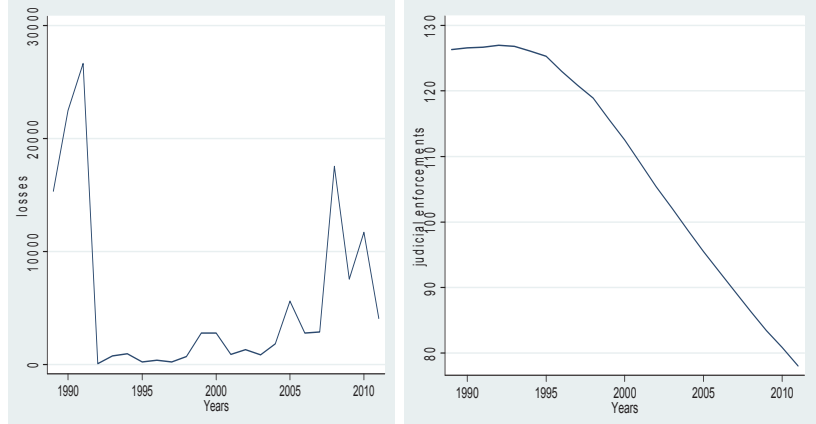

Note: Fig. 7 shows aggregate bank losses in years for banks in Nigeria losses dwindled in the early 1990s but have began to experience a significant increase in 2007 most of which are attributable to cases of management fraud. Fig 8 depicts legal rights enforcements it was captured using the average life span of legal litigations; this was used as a measure for bank oversight functions and regulatory measures.

Aggregate lending is also on the decrease and has not returned to the pre 1990 levels showing that most Nigerian commercial banks were falling short of their obligation to private organizations and were not helping to drive growth in the economy; past studies state that the major obligation of banks is lending to private individuals and organizations for further production purposes see Diamond (1984), Bhattacharya and Thakor (1993) and Foos, Norden and Weber (2007) for further discussion.

Aggregate income is on the increase and this is most noticeable from the early 2000 s till date, this would be probably reducing the rate of fraud occurrence in general in the banking sector since good remuneration of banking officials and the other probable corroborators in the financial sectors, this will be particularly true since the Nigerian economy has experienced some level of significant growth which is attributable to sustained high prices in commodities despite the global contraction.

Fig. 9. Aggregate Commercial Bank Lending Fig. 10. Average Income (proxy for wage rates)
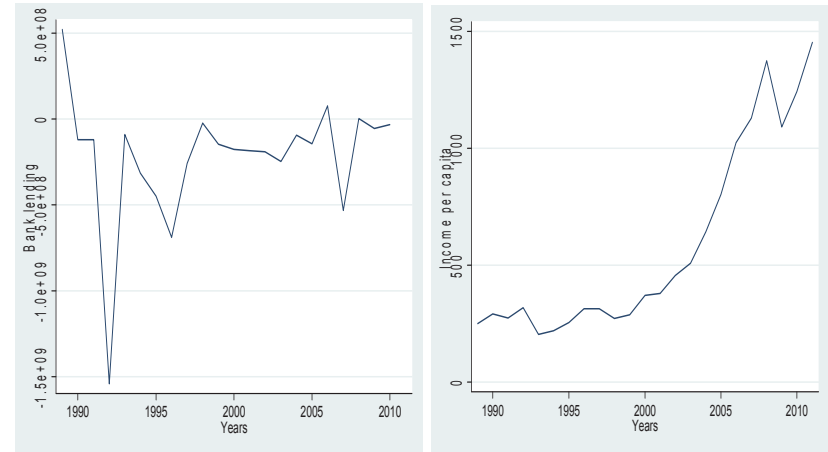
Note: Fig. 9 shows aggregate lending for the 23 years under study findings show that lending has been at an all time low Fig. 10 shows trend in GDP per capita in years this was used as a proxy for income which we express as wage rates for workers in the banking sector.

\section{Theory and Methodology}

Past studies have also investigated issues of fraud reduction and deterrence by recommending improvements in working environments in banks and increase in internal control using a survey of fraud reports obtained from NDIC 2003 to 2009 reports for Nigeria to make relevant inferences as to causes of high fraud occurrence in the Nigeria banking sector Adeyemo (2011).

Other studies such as Akindele (2011) also used primary data from questionnaires to investigate catalyst of fraud in the Nigerian banking sector finding that a host of factors were responsible for fraud in the Nigerian banking sector, they include lack of adequate training, poor communication gap and poor leadership skills which were responsible for high fraud occurrences in the Nigerian banking sector. The study by Foos, Weber and Norden (2007) also study loan growth and the riskiness of the business environment that often affect loan growth, that is likely to be responsible for bank aversion in granting loans making them to fall short of their major banking responsibility to the private sector of the economy by studying the relationship between loan growth and loan losses using vector auto regressive (VAR) model and found that loan growth peaked when losses accumulated considerably.

The Theory we rely on in this study is one in which fraud will depend on a host of factors such as bank deposits which will incite fraud, bank staffs wage rates which captures how conducive the banking environment is and will likely have some deterrence effect on fraudulent occurrence, commercial bank lending which will likely reduce aggregate bank gloat capital and channel them towards productive capabilities resulting in private sector profits and returns for banks, interest rates which capture the riskiness of the business environment and will likely affect lending, legal rights strength which captures regulatory strength and institutional capabilities in effecting internal controls to check fraud, aggregate bank losses that is likely to be due to incidence of fraud and is likely to have a positive effect on fraudulent occurrences and money supply which captures the impact of central bank policy on the banking sector.

Therefore factors such as the apex bank oversight activities will then be dependent on its bank policy implementation $(P I)$ and the strength of the judiciary represented by strength of legal rights $(S L R)$ since central banks oversight prosecution in cases of management fraud which make up over $75 \%$ of bank losses in Nigeria will be referred to courts this is expressed in equation 1.

\section{(1.) $C O=P I+S L R$}

The riskiness of the business environment will be also be a function of the apex banks regulatory strength known as the Central Bank oversight activities (CO), country specific monetary policy (MP) captured using money supply and average annual interest rates (IR) which will depict cost of access to capital this can be expressed below in equation 2 .

\section{(2.) $R E=C O+M P+I R$}

Bank lending $(B L)$, will reduce capital gloat in banks and will likely affect fraud occurrence negatively if aggregate bank lending is high. Lending in general will be affected by factors such as the riskiness of the business environment (RE) payroll accounts (PA) which will depict potential borrowing firm income or liquidity, reports from credit committees (RC) and cost of access to capital, captured by interest rates (IR) will also affect aggregate lending in commercial banks this is expressed below in equation 3.

\section{(3.) $B L=R E+P A+R C+I R$}

Deposits (DP) will now be affected by a host of factors such as depositors perception in banks as represented by the effectiveness of Central Bank oversight activities (CO), average income (IN), aggregate commercial bank lending $(\mathrm{BL})$ which will affect deposit interest rates since loans will be debt portfolios with returns accruing such portfolios, savings deposit interest rates (DI) which will be an incentive for customers to save, interest rates (IR) which will affect cost of access to capital, aggregate bank losses (LS) will affect depositors perception to save and lastly the apex bank monetary policy (MP) which is likely to affect bank viability expressed below in equation 4.

\section{(4.) $\mathrm{DP}=(\mathrm{CO}+\mathrm{IN}+\mathrm{BL}+\mathrm{DI}) /(\mathrm{IR}+\mathrm{LS}+\mathrm{MP})$}

Finally fraud (FR) will now be expressed as a an increasing function of three factors which include poor management (PM) in commercial banks, high interest rates (IR) which makes borrowers to be averse to accessing loans, deposit gloat or otherwise referred to high customer bank deposits (DP) and a decreasing function of four factors which include oversight functions of the apex bank (CO), income (IN) which will act as a deterrent to fraud, aggregate bank lending (BL) which will reduce deposit gloat and finally country specific monetary policy (MP) captured using money 
supply, expressed below in equation 5 .

\section{(5.) $F R=(P M+I R+D P) /(C O+I N+B L+M P)$}

Fraud can now be expressed as a function of all these factors: Fraud f(Deposits (DP), Bank Staff Wage Rates (IN), Bank Lending (BL), Interest Rates (IR), Legal Rights Strength (CO), Bank Losses (BL), Money Supply (MP)). The method of estimation used in the study is the quantile regression estimation method; this is a non parametric method of estimation that is based on the premise that sample median will tend to that of the distribution and produces consistent estimates in the presence of outliers, heteroscedastic errors see the qreg2 wrapper as proposed by Machando and Silva (2013). Also the bootsrapped quantile regression also addresses issues of data stringency since it produces the regression results of the resampled dataset allowing us to control for robustness of regression results. The model to be estimated can now be written as

(6.) $F R_{t}=\alpha_{0}+\alpha_{1} D P_{t}+\alpha_{2} X_{t}+\epsilon_{t}$

where fraud (FR) will depend on aggregate bank deposit (DP) and a host of exogenous factors $X_{t}$ such as wage rates, bank lending, interest rates, legal rights strength, bank losses, money supply that we identify to be likely responsible for fraudulent occurrences in the Nigerian banking sector where $\mathrm{t}$ is an index of time, $\alpha_{0}$ is a constant, $\epsilon_{t}$ is the error term. Deposits and all explanatory variables were lagged to resolve issues of multi-co linearity and model misspecification therefore fraud will depend on these factors from past periods.

\section{Data and Sources}

Times series data is used in this study, all data are obtained from Central Bank of Nigeria data set and World Development Indicators of the World Bank data unless otherwise stated for the period of 1989 to 2012 a period of twenty three years. Table 1 below also shows the list of all variables used in the study.

The dependent variable fraud is the sum in billions of Naira of all amount associated with fraudulent occurrences in years in the Nigeria banking sector. Deposit is the aggregate sum of all yearly customer deposit in Naira in banks obtained from CBN data, bank losses are declared losses by banks in Naira obtained from CBN data, FDI is the inflow of all foreign investment to

Table 1. List of Variables and Description

\begin{tabular}{|c|c|c|c|}
\hline Variables & Sources & Abbreviations & Description \\
\hline Fraud & Central Bank of Nigeria Data & FR & Aggregate commercial bank fraud in Naira \\
\hline Foreign Direct Investment & World Bank data & FDI & $\begin{array}{l}\text { Aggregate inflow of foreign investment into } \\
\text { Nigeria in USD. }\end{array}$ \\
\hline $\begin{array}{l}\text { Legal right strength(measure of } \\
\text { domestic institutions) }\end{array}$ & World Bank data & LR & $\begin{array}{l}\text { Measured using percentage of cases concluded } \\
\text { in courts per year. }\end{array}$ \\
\hline Deposits in Naira & Central Bank of Nigeria Data & DP & $\begin{array}{l}\text { Total annual aggregate customer savings } \\
\text { deposits in commercial banks in Naira }\end{array}$ \\
\hline Losses & Central Bank of Nigeria Data & LR & $\begin{array}{l}\text { Aggregate yearly commercial bank losses in } \\
\text { Naira }\end{array}$ \\
\hline Interest rates & Central Bank of Nigeria Data & IR & $\begin{array}{l}\text { Average yearly interest rates in years all in } \\
\text { percentages }\end{array}$ \\
\hline Income (Wage rates) & World Bank data & IN & Yearly GDP per capita \\
\hline Commercial Bank Lending & World Bank data & $B L$ & Aggregate commercial bank lending in USD \\
\hline Money Supply & Central Bank Data & MS & Aggregate money supply in years in Naira \\
\hline
\end{tabular}

Note: All data are obtained from Central Bank of Nigeria data and the World Bank world development indicator (WDI) data unless otherwise stated. The abbreviation USD represents United States Dollars. The dependent variable fraud is the sum in billions of Naira of all amount associated with fraudulent occurrences in years in the Nigeria banking sector. Deposit is the aggregate sum in billions of Naira of all yearly customer deposits.

The private sector of the Nigerian economy in constant USD, income is the average GDP per capita in USD, strength legal strength is a measure of judicial effectiveness using score data obtained from the world bank, bank lending is aggregate commercial bank lending to the private sector in constant USD, nominal interest rates is the average commercial bank lending in percentages and money supply is the aggregate money in circulation in constant USD. 


\section{Empirical Analysis and Results}

The argument presented in the study is that the spate of low commercial bank lending in the Nigerian banking industry and a host of other institutional and administrative deficiencies is probably responsible for high fraudulent occurrences in the Nigeria banking sector. Allowing us to put high bank deposit that is a common factor in many commercial banks in the fraud equation and assert that it is likely to be the a major cause of fraud occurrence in the Nigeria banking sector. This idea is probably supported by past literature which state that lending to the private sector is a primary function of commercial banks despite the riskiness that is often associated with loan growth and bank aversion in lending particularly in a risky environment like Nigeria's allowing us to buttress our argument that high bank deposit was driving fraud in Nigeria since commercial lending is low. The a priori assertion we rely on can therefore be stated as follows:

a.) High bank deposit will probably be driving cases of high fraud occurrences in Nigeria

b.) Commercial lending will probably have a negative effect on fraudulent occurrences in Nigeria.

c.) Interest rate will probably be having an indirect causal effect on fraudulent occurrences since it will probably be affecting borrowers' decisions in taking loans from commercial banks.

d.) Finally average wages of workers in the banking sector will probably be affecting fraud occurrences in a positive or negative manner since it depicts how conducive the bank working environment is for workers reducing the incentive derived by workers in collaborating to aid fraudulent occurrences.

\section{Results}

The results of the quantile regression estimates are presented below in table 2. The variable year was included to capture the differences in fraudulent occurrences in years and was not statistically significant showing that a host of other factors were also probably responsible for fraudulent occurrences other than high bank deposits which was probably true since the level of enforcement of legal rights were low and it was likely that other socio political factors were probably driving fraudulent occurrences in the Nigeria banking sector.

High bank deposits were found to be significantly promoting fraudulent occurrences in the Nigerian banking sector this was true for the quantile regression results in table 1 column 1 , since the bootstrapped simultaneous quantile regression results in table 1 column 2 and the results of the preferred quantile regression wrapper results (as developed by Machandos and Santos (2013)) in table 1 column 3 where we controlled for the presence of heteroscedastic errors due to the volatility of the fraud variable.

Commercial banks lending were found to be having a negative effect on fraud occurrences and the results were significant particularly for the regressions were we included the CBN Policy variable and interacted the same policy variable with $\mathrm{FDI}$ (policy* $\mathrm{FDI}$ ) which was a measure of investors perception of the Nigerian banking sector.

Interest rate also had a positive effect on fraud but was only significant in the quantile regression results in column 1 , but the robustness of the results was in doubt since the results of the bootstrapped quantile regression and the quantile regression (qreg2) wrapper had no significant effect on fraud.

Wage rates were also having a negative effect on fraud occurrences and the results were significant for all the regressions, except for the regression were we controlled for heteroscdastic errors of the fraud variable, see table 1 column 3 also making us to doubt the robustness of this results.

In the appendix we also present the results of the kernel density estimation and find some useful results, fraud occurrences were increasing with increases in deposits supporting the results of the quantile regression see fig. a in the appendix. High fraud incidents was also shrinking investor perceptions in general since the high rate of fraud occurrence was causing a reduction in the flow of foreign direct investment into the economy see fig $b$ in the appendix.

CBN policy were not very useful in effectively reducing fraud in the banking sector since it was exerting a mixed effect on fraud, as policy improved initially fraud occurrences shrank afterwards corroborators were probably beginning to find new ways to circumvent regulatory measures to perpetuate fraud see fig. $\mathrm{c}$ since further improvement in policy was not reducing fraud occurrences. Bank lending which have virtually been in an all time low were not having any effect on fraud occurrences see fig. $d$ validating the results of the quantile regression and offering further explanation on the identified factors that affect fraud occurrences. 
Table 2. Regressions of the Impact of High Bank Deposit on Fraud

\begin{tabular}{|c|c|c|c|c|c|}
\hline Variables & (1) Fraud & (2) Fraud & (3) Fraud & (4) Fraud & (5) Fraud \\
\hline Deposit & $\begin{array}{c}2.87^{\star \star \star} \\
(0.20)\end{array}$ & $\begin{array}{c}2.87^{\star \star \star} \\
(0.82\end{array}$ & $\begin{array}{c}2.95^{\star \star \star} \\
(0.75)\end{array}$ & $\begin{array}{c}2.76^{\star \star \star} \\
(0.62)\end{array}$ & $\begin{array}{c}2.92^{\star \star \star} \\
(0.54)\end{array}$ \\
\hline Losses & $\begin{array}{l}120.9 * \star \\
(51.67)\end{array}$ & $\begin{array}{c}120.9 \\
(143.4)\end{array}$ & $\begin{array}{c}70.43 \\
(388.3)\end{array}$ & $\begin{array}{l}149.9^{\star} \\
(84.65)\end{array}$ & $\begin{array}{l}117.9^{* \star} \\
(48.82)\end{array}$ \\
\hline Wage rates & $\begin{array}{c}-9.17 * \star \star \\
(2.39)\end{array}$ & $\begin{array}{c}-9.17^{\star \star \star} \\
(1.20)\end{array}$ & $\begin{array}{c}-6.36 \\
(1.81)\end{array}$ & $\begin{array}{c}-9.99^{* *} \\
(3.56)\end{array}$ & $\begin{array}{c}-10.96^{\star *} \\
(3.90)\end{array}$ \\
\hline Investment & $\begin{array}{c}-74.02 \\
(134.27)\end{array}$ & $\begin{array}{c}-74.02 \\
(217.38)\end{array}$ & & $\begin{array}{c}-16.64 \\
(177.16)\end{array}$ & $\begin{array}{c}73.59 \\
(191.06)\end{array}$ \\
\hline Interest rates & $\begin{array}{l}299.79^{\star *} \\
(120.55)\end{array}$ & $\begin{array}{c}299.79 \\
(706.72)\end{array}$ & $\begin{array}{c}212.75 \\
(967.82)\end{array}$ & & \\
\hline Oversight regulation & $\begin{array}{c}43.32 \\
(67.54)\end{array}$ & $\begin{array}{c}43.32 \\
(132.18)\end{array}$ & $\begin{array}{c}119.44 \\
(413.99)\end{array}$ & & \\
\hline Money supply & $\begin{array}{c}89.22 \\
(127.99)\end{array}$ & $\begin{array}{c}89.22 \\
(453.21)\end{array}$ & $\begin{array}{c}-7.90 \\
(687.85)\end{array}$ & & \\
\hline Bank lending & $\begin{array}{c}-0.001 \\
(0.001)\end{array}$ & $\begin{array}{c}-0.001^{*} \\
(0.0004)\end{array}$ & $\begin{array}{r}-0.0004 \\
(0.003)\end{array}$ & $\begin{array}{l}-0.001^{*} \\
(0.001)\end{array}$ & $\begin{array}{c}-0.001^{\star *} \\
(0.001)\end{array}$ \\
\hline Interest rates* FDI & & & $\begin{array}{l}-10.35 \\
(36.62)\end{array}$ & & \\
\hline CBN policy & & & & $\begin{array}{c}1.17 \\
(1.95)\end{array}$ & \\
\hline PolicyFDI & & & & & $\begin{array}{c}0.20 \\
(0.55)\end{array}$ \\
\hline Year & No & No & No & No & No \\
\hline Observations & 22 & 22 & 22 & 22 & 22 \\
\hline R-squared & & 0.40 & 0.42 & 0.39 & 0.39 \\
\hline
\end{tabular}

Standard errors in parentheses, ${ }^{* * *} p<0.01,{ }^{* *} p<0.05,{ }^{*} p<0.10$

Note: The results of the fraud regression using quantile regression technique is presented above, it shows that high customer deposits were increasing fraud occurrences in commercial banks. Improved wages were having a deterrent effect on fraud so also was increased bank lending to the private or real sector of the Nigerian economy.

\section{Discussions and Conclusions}

All the objectives of the study were realized and are discussed in this section as follows. Interestingly the study finds strong and convincing evidence that banks in Nigeria were failing in their primary role of lending to the private (real) sector which has the capability of driving and sustaining growth of the entire economy. The implication of this is that a review of the Nigeria commercial bank "modus operandi" is essential to ensure that commercial banks adhere and are alive to their primary responsibilities to the real sector despite the acknowledged riskiness of the current Nigerian business environment. Periodical review of wage rates for bank staffs is also recommended since wages often show how conducive the banking environment is to bankers and was found to be reducing incidents of fraud in the Nigerian banking sector.

Lending remain at an all time low due to the risky business environment in Nigeria while this keeps driving high deposits in banks it has far reaching implication for the private sector showing that fewer and fewer private sector businesses were having access to bank loans or were probably interested in taking lines of credit from banks owing to the stringent conditions associated with accessing capital in commercial banks in Nigeria. Interest rates were having no effect on fraud occurrence reduction in the Nigeria banking sector this was as a result of the increase in interest rate due to the 2007 financial crisis, making the assertion that it was probably driving fraud occurrence through indirect causation to be likely true since it was preventing lending and increasing deposit gloat.

Oversight regulation had no effect on fraud reduction showing that poor over sight function by regulatory bodies were still a problem responsible for high fraud occurrences in the Nigerian banking sector. Internal controls were also probably weak and having little or no effect on fraud reduction as a whole. Finally fighting fraud remains a hard task, high bank deposit accumulation by commercial banks should be viewed as a probable factor that can drive high fraud occurrences in Nigeria, the policy implication of this finding is that wage rates and lending to the private sector has strong 
capabilities of reducing fraudulent occurrences in the Nigeria banking sector and bank staff wages should remain under periodical review by fraud regulatory agencies and other concerned agencies in the Nigerian banking sector.

\section{Acknowledgments}

We express thanks to Dr Ikpefan of Department of Banking and Finance Covenant University Ota Nigeria for the motivation to write this paper. We also express thanks to Dr (Mrs) Deborah Odejimi the Head of Department of Economics and Development Studies Igbinedion University Okada for providing support for this research and her strong incites and contributions.

\section{References}

Adeyemo (2012) "Frauds In Nigerian Banks: Nature, Deep-Seated Causes, Aftermaths And Probable Remedies" Mediterranean Journal of Social sciences Vol.3 (2).

Adewunmi, W. (1986), "Fraud in banks, Nigeria institute of bankers", Land mark publication, Lagos.

Ajisebutu, A. (2006), "Financial Statement Fraud: What Auditors should know", The Nigerian Accountant, 39(2), p17

Akindele, R. I. (2011). "Fraud as a negative catalyst in the Nigerian banking industry". Journal of Emerging Trends in Economics and Management Sciences, 2(5), 5357-363.

Bernanke, B. S. and Kuttner, K. N. "What Explains the Stock Market's Reaction to Federal Reserve Policy?" Journal of Finance, 2005, 60(3), pp. 1221-58.

Cahill, Chen, Lambert, Pinheiro and Sun (2002) "Detecting Fraud In The Real World" Bell Labs and Lucent Technologies Publications

Crosse H.D and Hempel. G.H. (1973) "Management politics for commercial banks" pp 242-245

Cortesao L., Martins F.: Rosa A., Carvallio P. (2005) "Fraud Management Systems in Telecommunications": A practical Approach. ICT FMS

Diamond, Douglas W., and Philip H. Dybvig. 1983. "Bank Runs, Deposit Insurance, and Liquidity." Journal of Political Economy 91 (5): 401-19.

Diamond, Douglas W. 1984. "Financial Intermediation and Delegated Monitoring." Review of Economic Studies 51 (July): 393-414.

Fakunle, B. (2006). "Audit Companion", 2nd Edition. Lagos: L and Mark Publication

Foos D. Weber L. and Norden M., (2007) "Loan Growth and Riskiness of Banks" FDIC Working Paper.

Holmstrom, B., and J. Tirole. 1998. "Private and Public Supply of Liquidity." Journal of Political Economy 106 (1): 1-40.

Idowu, I. (2009). "An Assessment of Fraud and its Management in Nigeria Commercial Banks", European Journal of Social Sciences, Vol.10 (4), 628-640.

Jacklin, C. J. 1987. "Demand Deposits, Trading Restrictions, and Risk Sharing. In Contractual Arrangements for Intertemporal Trade", eds. E.C. Prescott and N. Wallace.

Minneapolis,MN: University of Minnesota Press: 26-47.

Ogwuma P.A (1985) "Problems and prospects of the Nigeria Banking industry". Seminar by: the financial institutions training centre. Pp5-7 


\section{Appendix I}

Fig a.

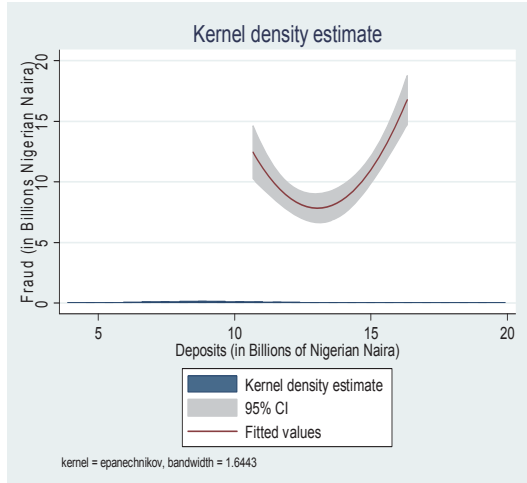

Fig b.

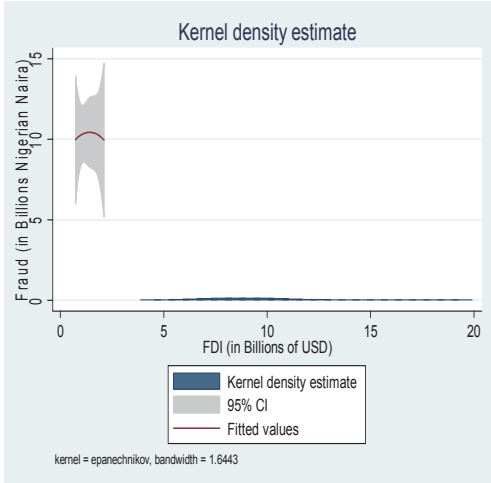

Note: Fig a shows the relationship between fraud and deposits, as deposit increased fraud occurrences increased though no immediately, while fig b shows that high fraud occurrences were limiting FDI inflow to the country since investors had poor perception of the institutional structures and banking sector of the country.

Fig. c

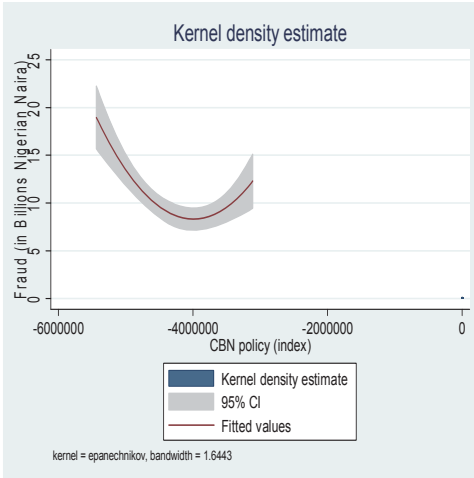

Fig.d

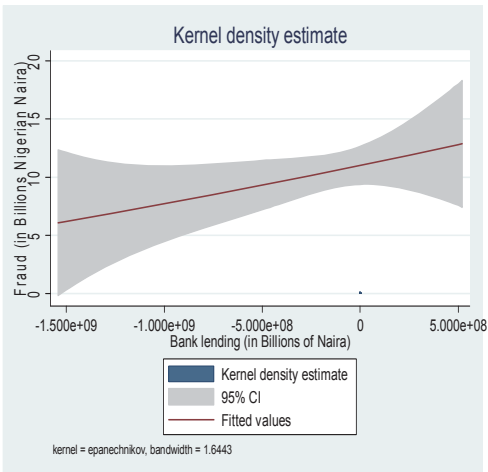

Note: Fig c shows the relationship between fraud and CBN policy, initially as policy improved fraud occurrences decreased, however at some point management fraud perpetuators were probably able to circumvent CBN oversight policies and perpetuate fraud since fraud increased with increase in policy oversight. The relationship between fraud and lending is a linear one lending is still very low and increased lending at high interest rates as it stands were promoting fraud occurrences. 
ISSN 2239-978X

ISSN 2240-0524
Journal of Educational and Social Research MCSER Publishing, Rome-Italy
Vol. 4 No. 6 September 2014 